\title{
Canon Formation and Children's Literature during the May Fourth Period
}

\author{
Chu Shen \\ Tsinghua University
}

Follow this and additional works at: https://docs.lib.purdue.edu/clcweb

Part of the Comparative Literature Commons

Dedicated to the dissemination of scholarly and professional information, Purdue University Press selects, develops, and distributes quality resources in several key subject areas for which its parent university is famous, including business, technology, health, veterinary medicine, and other selected disciplines in the humanities and sciences.

CLCWeb: Comparative Literature and Culture, the peer-reviewed, full-text, and open-access learned journal in the humanities and social sciences, publishes new scholarship following tenets of the discipline of comparative literature and the field of cultural studies designated as "comparative cultural studies." Publications in the journal are indexed in the Annual Bibliography of English Language and Literature (Chadwyck-Healey), the Arts and Humanities Citation Index (Thomson Reuters ISI), the Humanities Index (Wilson), Humanities International Complete (EBSCO), the International Bibliography of the Modern Language Association of America, and Scopus (Elsevier). The journal is affiliated with the Purdue University Press monograph series of Books in Comparative Cultural Studies. Contact: <clcweb@purdue.edu>

\section{Recommended Citation}

Shen, Chu. "Canon Formation and Children's Literature during the May Fourth Period." CLCWeb: Comparative Literature and Culture 16.6 (2014): <https://doi.org/10.7771/1481-4374.2302>

This text has been double-blind peer reviewed by $2+1$ experts in the field.

The above text, published by Purdue University Press @Purdue University, has been downloaded 413 times as of $11 /$ $07 / 19$.

This document has been made available through Purdue e-Pubs, a service of the Purdue University Libraries. Please contact epubs@purdue.edu for additional information.

This is an Open Access journal. This means that it uses a funding model that does not charge readers or their institutions for access. Readers may freely read, download, copy, distribute, print, search, or link to the full texts of articles. This journal is covered under the CC BY-NC-ND license. 


\section{PURDUE}

UNIVERSITY PRESS <http://www.thepress.purdue.edu>

\section{CLCWeb: Comparative Literature and Culture}

ISSN 1481-4374 <http://docs.lib.purdue.edu/clcweb> Purdue University Press @Purdue University

CLCWeb: Comparative Literature and Culture, the peer-reviewed, full-text, and open-access learned journal in the humanities and social sciences, publishes new scholarship following tenets of the discipline of comparative literature and the field of cultural studies designated as "comparative cultural studies." In addition to the publication of articles, the journal publishes review articles of scholarly books and publishes research material in its Library Series. Publications in the journal are indexed in the Annual Bibliography of English Language and Literature (Chadwyck-Healey), the Arts and Humanities Citation Index (Thomson Reuters ISI), the Humanities Index (Wilson), Humanities International Complete (EBSCO), the International Bibliography of the Modern Language Association of America, and Scopus (Elsevier). The journal is affiliated with the Purdue University Press monograph series of Books in Comparative Cultural Studies. Contact: <clcweb@purdue.edu>

\section{Volume 16 Issue 6 (December 2014) Article 10 Chu Shen, \\ "Canon Formation and Children's Literature during the May Fourth Period" <http://docs.lib.purdue.edu/clcweb/vol16/iss6/10>}

Contents of CLCWeb: Comparative Literature and Culture 16.6 (2014) Special Issue Western Canons in a Changing East Asia. Ed. Simon C. Estok <http://docs.lib.purdue.edu/clcweb/vol16/iss6/>

Abstract: In her article "Canon Formation and Children's Literature during the May Fourth Period" Chu Shen discusses the translation of children's literature as a site in which nationalism is mirrored and is in turn constructed. For the New Culturalists during the May Fourth Period (1915-1927), nationalism was mirrored through a progressive cultural and literary agenda that included the translation of foreign literatures and hence contributed to canon formation. Shen's study refers to the importance of the study of translation with regard to topics of nationalism in the May Fourth period and it advances our knowledge not only about an important transitional period of modern Chinese history, but also about an often neglected genre and its cultural, literary, and ideological significance. 


\section{Chu SHEN}

\section{Canon Formation and Children's Literature during the May Fourth Period}

Writing about nationalism during the May Fourth Period (1915-1927), Jerome B. Grieder sums up the crux of the problem: "Nationalism in the May Fourth era manifested itself as a concern for the invisible foundations of the social order, a problem of cultural identity at the level of both individual and collective self-consciousness" (209). Grieder understands nationalism as related to China's cultural identity. Despite their many differences in theorizing the nation, theorists allow for the primacy of culture in the notion of nationalism (see, e.g., Anderson; Gellner; Plamenatz; Smith). In the modern Chinese context, the majority of scholars tend to associate the cultural dimension of nationalism with a conservative tendency: that which is culturally conservative is culturally nationalistic. "Cultural" nationalism, for them, translates into a loyalty to a nation's traditional culture which is seen as its symbol and lifeblood (see, e.g., Tao). This explains why research on cultural nationalism as it relates to China's radicalized and iconoclastic New Culture is lacking (for an exception, see Luo). I argue that cultural nationalism should not be equated with cultural conservativism. Instead, in early twentieth-century China, cultural nationalism could be understood as an approach that uses culture as a means to solve the nation's societal and political problems. In Western scholarship, for example John Plamenatz's conceptualization can lend us some insight: he wrote that "the desire to preserve or enhance a people's national or cultural identity when that identity is threatened, or the desire to transform or even create it where it is felt to be inadequate or lacking" (45). The two possible manifestations of "desire" Plamenatz speaks about is perhaps nowhere more explicit than in the early twentieth-century China where the New Culturalists, faced with a crisis, resorted to "transform" or "create" a new identity for China while their more conservative contemporaries sought desperately to "preserve" the traditional Chinese cultural identity. Seen in this way, it may be said that the two parties shared the same broad aims. What was different was how they believed their aims might be achieved. For the New Culturalists, the modernity they sought was predicated on the "importation" of Western thought including literature in translation (see, e.g., Liu). In their modernizing project, Shi Hu (1891-1962) and his like-minded colleagues adopted what Yu-sheng Lin identifies as a "cultural intellectual" approach in emphasizing literature as a vehicle for societal change (26-27). Translated literature thus took on an important educational and ideological function in the transitional May Fourth period. In particular European romantic and realist literature with its humanist and individualist ethos were popular among advocates of the New Literature movement who worked as intellectual-translators in 新青年社 (New Youth Society) and 文学研究会 (Society for Literary Research) established in 1920 to carry forward the tenets of the movement. Shi $\mathrm{Hu}$, for instance, translated and interpreted Ibsen's A Doll's House to develop an ideal notion of individualism. Xun Lu (1881-1936) and Zuoren Zhou's (1885-1967) contributions in both translation and theoretical work regarding the problematic of individual power and consciousness were also prominent, which is partly attributable to their experiences in Japan where European Romanticism occupied center stage at the beginning of the twentieth century. Both Zhenduo Zheng (1898-1958) and Moruo Guo (1892-1978), despite their differences in the theory and practice of literature, embraced Rabindranath Tagore whose focus on the liberation of individuality was an important perspective both sought to emulate.

The question then is as to how the "supremacy" of individualism conforms to and reconcile with New Culture nationalism? It seems to me that individualistic values never run counter to the discourse of nationalism, but in fact constitute a defining feature of New Culture nationalism. This could be seen as a radical statement, especially when May Fourth nationalism is too often held responsible for "jeopardizing the project of enlightenment, of which individualism formed an integral part" (see, e.g., Liu 83). The problem, as I see it, boils down to an arbitrary opposition established between nationalism and enlightenment in the early twentieth-century Chinese context, an opposition that sees the two as irreconcilable. New Culture nationalism, however, embodies important aspects of enlightenment ethos, although the meaning of "enlightenment" itself is subject to change in the Chinese context (see, e.g., Zhang). During the May Fourth period individualism as a discourse imported from the West was used as a convenient weapon to attack traditional Chinese cultural values the New Culturalists sought to obliterate, for these values established strict hierarchy within a society that required absolute loyalty 
to the father, the husband, the emperor, and the monarchy at the expense of individual development. Xun Lu, in his 1918 short story "狂人日记" ("A Madman's Diary"), exposed the devastating toll this ethic took on the individual. Yu Wu in his article "吃人与礼教" ("People-eating and Feudal Ethics") published in 1919, followed on from Lu's story and lashed out at the ethic with historical facts. For the New Culturalists, these anti-individualistic values were taken to be the root cause for the nation's trauma. Individualism, in other words, was used to wage war on the traditional Confucian order, for the nation would not survive with Confucianism in the reign: "the survival of the established conventional Confucian order as a total system" was no longer compatible with "the survival of China as a socio-political entity" (Benjamin 100). Here, the question of individualism, in its decisive break with the past and with tradition, also brings out the temporal dimension of New Culture nationalism.

The nation, however, was imagined not only in its temporal dimension, but also within the spatial dimension of the "world" in which China found itself. New Culture nationalism was by no means a narrow or parochial ideology concerned exclusively with the nation itself; rather, it carried some transnational and cosmopolitan elements. When Zuoren Zhou advocated "人的文学" (humanist literature) his premise was "the love for humanity" (154). In "新文学的要求" ("Requirements for a New Literature"), another foundational text in modern Chinese literature, Zhou states that the new literature, instead of being confined to a particular race, nation, locality, or family, belongs to the whole humanity (18-23). Literature, in other words, should be informed with a humanism that sees each individual human as transnational. At a time when China was so out of pace with the modern world, Zhou and others sought to find it a place through the humanist literature. In the aftermath of 1918, a critical discourse which had been fermenting over the years became entangled with New Culture nationalism to the point that one cannot speak of one without invoking the other. "世界主义" (shijie zhuyi; cosmopolitanism), in the post-1918 environment, provided the theoretical basis for unleashing the human potential beyond the shackles of the nation-state. On the May Fourth literary horizon, cosmopolitanism was inevitably linked with the idea of world literature. Zhou's words in a 1923 essay entitled "旧梦" ("Old Dreams") lend much insight into this connection. It also suggests a fluid and reconcilable relationship between the local and the global: "People in our times have developed a self-conception of 'Kosmopolites' in the revolt against the provincial statism ... Unwilling to relinquish the cosmopolitan attitude, I am, however, more driven toward the local ... I treasure local art and literature in the belief that strong local flavor is part and parcel of 'world' literature. The value of 'world' literature lies in its multifaceted flavors and tastes" (153).

"World literature" as Zhou articulated it was very much the result of selection, translation, and compilation, and the nature of this "world" is immediately perceivable through literary translation. The "world" to which China turned was selective. It was a "world," but one that was perceived through nationalistic eyes. In their selection of "world" literary texts, translators were aiming primarily for two types of texts: those intended to aid China's modernization, such as those from the West and Japan whose modernity China aspired to and the others were associated with the reaction against imperialism. As a result, in addition to Indian and Irish, the literatures of other European countries including Polish, Hungarian, Czech, and Finnish were of interest to Chinese translators including Zhou. Struggling under imperial power, Chinese intellectuals thus reached out to literatures of those countries which resonated with them (on this, see, e.g., Chen, Yugang). Hence my suggestion that by providing a relational perspective that links China with the "world" it encountered, the history and processes of literary translation would assist studies of early twentieth-century Chinese culture and intellectual history. In the same essay mentioned above, Zhou cited various examples of truly "humanist literature" including Ibsen's A Doll's House and The Lady from the Sea, Tolstoy's Anna Karenina, Hardy's Tess of the d'Urbervilles, and texts by Dostoyevsky and Tagore. Of note is that the woman protagonist in most of the works Zhou mentioned was indeed no coincidence. Rather, it revealed the importance of the question of the individual, in this case the woman, as part of the national question. As Joan Judge points out, in the nationalist agenda "the national question" and "the women's question" were confronted simultaneously (765). It is clear that at a time when the cultivation of the individual was crucial to the national cause and when "the line between academic and political education was impossible to draw" (Grieder 153), the fictional and real paradigm of the woman became an important factor of culture and nation and thus translated literature was envisioned as a tool to cultivate and construct the "new woman" of the emerging Chinese nation. In her book Tales of Translation Ying Hu traces the 
production and circulation of Western women icons in the early twentieth-century Chinese context and unravels the dynamic historical forces which led to the fictional and translational re-workings of these women models: "As the voice of the foreign blends into one's own voice, the battle of nationalism is fought on the ground of language, ideological warfare displaced onto warfare over the proper medium for literature" (11). In The New Woman in Early Twentieth-Century Chinese Fiction, on the other hand, Jin Feng explores male writers' representations of the new woman and pays particular attention to the interaction between text and context, to the "social, historical and cultural intention which motivated the production of literary texts", revealing that the depiction of the new woman "was often tailored to fulfill a variety of explicit political ends" (16). Indeed, the figure of the woman was caught in various political agendas: the modernizing movement, the enlightenment project, and above all, the nationalist cause. Thus in the Chinese case translated literature in the period discussed was established as pertaining to a specific canon different from that of the canon in the literatures of the West themselves.

Alongside the woman, however, stands another figure that is often neglected by scholars of modern Chinese literature, namely the figure of the child. Like women, children were conceived as part of the national question. When he championed a humanist literature, Zhou indeed had both women and children in mind, the discovery of whom he saw as a natural extension of the discovery of the individual. Reforming the mind of children thus represented a crucial step toward reforming the individual in the transitional period of the early twentieth century. From a comparative perspective, children's literature usually assumes a greater educational role in societies which experience a phase of transition from traditional to modern (see, e.g., O'Sullivan 62). In the Chinese context, the education of children in fact relied more heavily on texts in translation, compared with the construction of the new woman that drew its inspiration from both Western and traditional sources. The reason, I argue, lies in the inertia facing the transformation of China's culture as a result of the insidious, ongoing processes in which a national culture is transmitted and passed down from one generation to the next via different institutional and individual channels. To counterbalance the negative forces in cultural transmission, the figure of the child as a "blank slate" would naturally be the best site from which to start the process of change and transformation. Andrew F. Jones, in his Developmental Fairy Tales, contends that educating the child, indispensable as part of the discourse of development, was "central to the ideology of nation-building in Republican and post-1949 China alike" (104). In the late Qing period, efforts in translating children's literary works were beginning to pick up momentum. A majority of these works, however, were not necessarily translated with the cultivation of human-individuals out of children as an end-goal. 十之九 (Nine Out of Ten), labeled a social novel, was exactly such an example. Some works, such as Lu Xun's translation of Jules Verne's Journey to the Center of the Earth which was done in classical Chinese, did indeed aim to reform and open up people's minds, they nevertheless did not necessarily target children as readership. In fact, with classical Chinese as the dominant translating language, children below school age were automatically excluded from readership.

During the May Fourth period an unprecedented endeavor was launched by proponents of the New Literature movement that aimed to construct a genuine literature for children via the means of translation. The prominence of translation in this case was also partly enabled by the belief that translation could help create a vernacular language and literature in dire need and which would also be best suited to the ears and sensibilities of children (for how translation could be used to create a vernacular language, see, e.g., Qu and Lu). In their effort to transport specific genres of children's literature such as fairy tales, fables, and children's plays, etc., the translators had specific images of children in their mind and unto whom they projected the hope of a better future for the nation. Indeed, as Jones puts it, the child had long been seen as an "object of ideological investment" (23). It is in their translated works and analytical essays that the ethos of New Culture nationalism can be both glimpsed and further defined. In what follows, I outline a few defining features which can serve to illustrate the processes of canonization during the period. The translators mentioned below-including Xun Lu, Zuoren Zhou, Zhenduo Zheng, and Dun Mao-are recognized in the Chinese context more as intellectuals and writers rather than translators. Their work in translation, however, paved the way for a modern Chinese children's literature. Although starting from the early 1920 s owing to changing national circumstances, their views regarding children's literature diverged into two different camps with Zhou and 
Zhao continuing to embrace Western romantic notions of childhood while the others moved on to a more realist and politicized revolutionary agenda.

If we observe closely the translators' prefaces and analytical studies written in the first years of the Republic, we notice a marked break with late Qing translations in two significant ways: first, explicit moralizing in an effort to consolidate feudal rule, which so typically infiltrated late Qing translations, were denounced, and second, any conscious adaptations to manipulate children's texts in accordance with sophisticated adult thinking were rejected. A notable example is the translation of Andersen's tales: the late Qing version 十之九 (Nine out of Ten) translated by Jialin Chen and Dadeng Chen was in classical Chinese. The texts were adapted and changed in such a way that, according to Zhou, no traces of Andersen were found. In his essay on the translation which was entitled "随感录 二 四" ("Random Thoughts 24"), Zhou spoke out against the ruthless change of Andersen's child language into rigid and monotonous texts perpetuated with moral teachings designed for adults thus stripping the tales of Andersen both the lively child language and ways of appealing in language to children. Analyzing the work of Zhou, Liqun Qian writes that the spirit of the children's minds and speech is "a primal life force" associated with nation building (158). Indeed, the cultural primordial was evoked to reject the moral high ground that was feudalistic and seen as an impediment in the cultivation of free individuals for a new Republican nation. Zhou's "radical" reevaluation of Andersen's tales, widely applauded by like-minded translators at the time such as Zhenduo Zheng, Dun Mao, and Jingshen Zhao, produced a transformative impact on the way fairy tales were to be translated and received in the Chinese context.

One of the most notable changes in terms of content was the inclusion of stories of talking plants, beasts, and animals and the celebration of the merging of the human and the animal world. This was again made possible by the gradual importation and establishment of the fairy tale as a genre in Chinese children's literature. When it was first championed by Zhou, the fairy tale with its subversion of the hierarchy between humans and animals was opposed by Confucian adherents (see, e.g., Jiang 23). The simple act of "deconstruction" enabled by the fairy tale had the potentiality to shake Confucian hierarchies to the core while introducing Western ideas of evolution and progress to Chinese children. I argue that in rejecting old moral codes, the fairy tales in fact helped construct a new form of morality considered necessary for the building of the modern Republican nation, a morality which was predicated not on the external sources of authority such as the emperor or the father figure as was the case with traditional children's literature, but on the thinking, reflective modern individual able to make moral judgments based on critical thinking abilities. Through vivid storytelling, translators of fairy tales taught children the value of persistence, the importance of honesty, and the difference between kindness and evil. Zheng's translations serve as a good case in point as he would consciously insert brief educational remarks toward the end of the texts as a way to help children grasp the meaning of the stories. For example, in "两个生瘤的老人" ("Two Elders with Tumors") where the different fates of two old men are contrasted, Zheng added his own comments to reinforce the theme of the story. Although translators such as Zhou would not have approved the act of intervention on the part of the translator, the fact remains that whereas the life of children was previously confined to the family and traditional schooling, fairy tales opened up the world for children and ushered in new possibilities of learning. With an increased emphasis on desirable inner human qualities, translated fairy tales encouraged the cultivation of the modern individual suited to the requirements of the modern Republican nation.

In the nationalist climate of the late Qing and early Republican period, science assumed an important place in the project of national salvation and thus science fiction acquired enormous popularity with intellectuals such as Xun Lu who "maintained that "科学小说" (science fiction) could open the Chinese people's mental horizons and propel social and intellectual evolution" (Wang 252). Lu himself translated Verne's science fiction which prioritized "science" rather than "fiction." Yet, the quest for a scientific worldview did not fully emerge until the May Fourth era (see Furth 62). A unanimous emphasis on imparting scientific knowledge was embraced by translators of children's literature during the May Fourth period resulting in the popularity of science stories for children. Zheng, who served as the editor of 儿童世界 (Children's World) in the early 1920s, was intent on incorporating scientific material in his journal: "We feel that not enough scientific knowledge is being imparted to children ... What we need to do ... is to open children's eyes to scientific knowledge in a way that stirs up their interests" 
(Children's Literature 86). Zheng himself translated "The Tree-Dwellers" by K.E. Dopp, a long interesting story about pre-historic human life. Throughout the translation, he made adjustments to the text which provided background scientific information for the Chinese children who were lagging behind in their acquisition of knowledge about nature and life. Zuoren Zhou embraced and disseminated knowledge of natural science by translating stories about the natural world such as the works by JeanHenri Casimir Fabre. Dun Mao, an important ally of Zheng in 文学研究会 (wenxue yanjiu hui; Society for Literary Research), an organization crucial to the development of a new children's literature in China, began his literary endeavors by translating science stories, most notably of which was 衣食住 (Food, Clothing, and Shelter) (1918), a book-length translation about the beginnings of human life. In the numerous translated myths and legendary tales published in Children's World in the beginning of the 1920s, Mao made an effort to insert explanatory remarks where necessary-about the causes of natural phenomena or the origins of life, etc. - so that children might pick up scientific knowledge while having fun with the tales.

An interesting combination of the heroic and the ordinary stands as another enchanting characteristic of May Fourth translations of children's literature. With the imperative of nationalism, the popularity of heroic tales-usually in the form of myth and legend-seems self-explanatory. Both Zhou and Zheng for example were known for translating Greek mythological tales. Characters such as Hercules and Prometheus gradually became familiar figures of hero to Chinese readership, children and adults alike. In his late years, Mao recalled a successful speech to middle school students that highlighted the story of Prometheus (The Road 302-03). I suggest that the preference for hero stories during the May Fourth period carried forward the romantic ethos of the late Qing period when both Lu and Zhou celebrated heroic individuals from foreign cultural and literary sources, not just through their polemical writings but also through translated works, as revealed by metatextual material accompanying their translations (see, e.g., Lu 9; Zhou 3). It is only understandable that in the imagining of the link between children's agency and social transformation, hero tales would be called upon to teach children the value of hardships and endurance that were meant to develop in children qualities perceived essential for China's nation-building endeavor: courage, confidence, integrity, and inner strength. It is important to recognize, however, that alongside tales of heroes there was also the simultaneous celebration of the life and the world of ordinary people. The protagonist in Lu's 小约翰 (Little Johannes), for example, is an ordinary child. The story narrates his life adventures as he faced the harsh realities of the world. Intellectually curious and passionate, little Johannes cherished hopes in times of uncertainties and never gave up faith. Eventually, he found meaning in serving the greater good of those around him. Like little Johannes, protagonists in children's stories depicted by translators such as Mao and Zhao might be ordinary people, but they have a positive attitude towards life and great emotional strength that gains them the respect from readers. The interesting mix of due celebration of the life of ordinary people and passionate eulogy of heroic figures is thus an important phenomena in the May Fourth children's literature and this illustrates the tensions inherent in the construction of the modern individual for the new Republic.

In addition to the points mentioned above, there was also a consistent emphasis on conveying artistic beauty. Whereas traditional children's literature were meant to teach children how to follow and obey to meet the requirements of the Confucian order, translators during the May Fourth period were interested to develop an appreciation of artistic beauty in children. This awareness was manifested in different ways: in addition to conveying inherent artistic beauty texts, both Xun Lu and Zhenduo Zheng were intent on using beautiful sketches or drawings to accompany their stories. An interesting characteristic of Zheng was the large number of drawings which appeared alongside the tales. Both Zheng and Xin Bing praised magical artistic beauty and the range of noble human emotions embodied in Tagore's poetry and Bing's own numerous writings for children were indebted to Tagore's Stray Birds. Indeed, the May Fourth translators and writers eulogized in a sentimentalist fashion not only the beauty and innocence of the child's heart, but also the value of natural emotional experience which was literally absent in the conception of children's literature in traditional Chinese society. Sentimentalism, a defining feature of the emergence of the modern individual, was also instrumental in nurturing children in May Fourth China. It seemed, therefore, that for literature to carry out its utilitarian function of social change, one crucial intermediary step was to cultivate individual souls and for the nation to prosper, children must be the first to be elevated to a state of modern culture. It is also in 
the task of cultivating the individual-a theme so central to New Culture nationalism-that the enlightenment imperative of the New Culturalists was made the most apparent. It was supposed to be a gradualist, incremental process until changing circumstances in the mid-1920s turned most intellectuals revolutionary again.

It could not be overemphasized that the "transnational" character of New Culture nationalism presented itself in translated children's literature as a cosmopolitan consciousness made possible by a profound "love for humanity" which Hao Zhang identifies as something close to a "new religion" and by the recognition of the noble emotions innate in each human being on earth. What Zheng writes about Tagore sums up the crux of the paradox for children's literature advocates: "Love for mankind and the advocacy for national liberation co-exist peacefully ... There is no contradiction between the two" (107). Here we detect a reconcilable relationship between love for one's own nation and love for humanity. Both Hao Zhang and Zhitian Luo called attention to the interesting coexistence of nationalism and cosmopolitanism in the May Fourth era. Luo also went a step further to analyze Hu's nationalism which he maintained was deeply mediated by cosmopolitan thinking. It seems to me that this particular nationalism was indeed shaped and defined by a cosmopolitan consciousness which gave it an open, embracing quality that characterized and at the same time justified much of its agenda, the most representative of which I contend was literary translation, and translated children's literature was an ideal site in which we can begin to examine this cosmopolitan consciousness. The complexities of the Chinese intellectual landscape condition the vastly different manifestations of nationalist sentiments. For the New Culturalists, nationalism was mirrored through a progressive cultural and literary agenda. And I maintain that the role of translation should never be overlooked for it both reflects and constructs the nation/individual/world triad which is crucial to an understanding of New Culture nationalism and even modern Chinese intellectual history. That literary translation is still given short shrift in current studies of nationalism on a political and intellectual level-even during a time when the social function of literature was most prominent-testifies to the reluctance to cross-disciplinary boundaries and to adopt relational perspectives which are in dire need in the humanities. Starting from the 1920s, ideological splits deepened among the New Culturalists. Hu and the like-minded continued to insist on nation building through culture and literature, but politics-minded intellectuals were more prone to engage directly with politics. The picture of nationalism became even more complicated, at least temporarily, until escalating political crisis compelled even the most cosmopolitan-spirited intellectuals such as Zhou to resume a nationalist stance.

Note: "Canon Formation and Children's Literature during the May Fourth Period" is a revised version from Chu Shen, Between Nationalism and Cosmopolitanism: Translation of Children's Literature in Early Twentieth-Century China. Ph.D. Diss. Beijing: Tsinghua U, forthcoming. Copyright release to the author.

\section{Works Cited}

Anderson, Benedict R. O'Gorman. Imagined Communities: Reflections on the Origin and Spread of Nationalism London: Verso, 1991.

Bing, Xin (冰心). 繁星 /春水 (Twinkling Stars / Spring Rain). Nanjing: Shaonian ertong chubanshe, 2010.

Chen, Jialin (陈家麟), and Dadeng Chen (陈大镫). 十之九 (Nine out of Ten). Shanghai: zhonghua shuju, 1918.

Chen, Yugang (陈玉刚). 中国翻译文学史稿 (Historical Materials for Translated Literature in China). Beijing: zhongguo duiwai fanyi chuban gongsi, 1989.

Eeden, Frederik van. Little Johannes. Trans. Clara Bell. Charleston: Nabu P, 2012.

Eeden, Frederik van. 小约翰 (Little Johannes). Trans. Xun Lu (鲁迅). 鲁迅大全集 (Collected Works of Lu Xun). Wuhan: Changjiang wenyi chubanshe, 2011. 293-389.

Emerson, Rupert. From Empire to Nation: The Rise to Self-assertion of Asian and African People. Cambridge: Harvard University Press, 1960.

Feng, Jin. The New Woman in Early Twentieth-Century Chinese Fiction. West Lafayette: Purdue University Press, 2004.

Furth, Charlotte. "May Fourth in History." Ed. Schwartz, Benjamin I. Reflections on the May Fourth Movement: A Symposium. Cambridge: Harvard University Press, 1973. 59-68.

Gellner, Ernest. Nations and Nationalism, Oxford: Basil Blackwell, 1983.

Grieder, Jerome B. Intellectuals and the State in Modern China: A Narrative History. New York: The Free P, 1981.

Hardy, Thomas. Tess of the d'Urbervilles. New York: Dover, 2001.

Hobsbawm, Eric J. Nations and nationalism since 1780: programme, myth, reality. Cambridge: Cambridge University Press, 1990.

Hu, Ying. Tales of Translation: Composing the New Woman in China, 1899-1918. Stanford: Stanford University P, 2000 
Ibsen, Henrik. A Doll's House; The Wild Duck; The Lady from the Sea. Trans. R. Farquharson Sharp and Eleanor Marx-Aveling. London: Dent, 1958.

Jiang, Feng (蒋风)，ed. 中国儿童文学讲话 (Talks in Chinese Children's Literature). Nanjing: Jiangsu wenyi chubanshe, 1959.

Jones, Andrew F. Developmental Fairy Tales: Evolutionary Thinking and Modern Chinese Culture. Cambridge, Massachusetts: Harvard University Press, 2011.

Judge, Joan. "Talent, Virtue, and the Nation: Chinese Nationalisms and Female Subjectivities in the Early Twentieth Century." American Historical Review 106.3 (2001): 765-803.

Karl, Rebecca E. Staging the World: Chinese Nationalism at the Turn of the Twentieth Century. Durham: Duke University Press, 2002.

Kedourie, Elie (ed.). "Introduction." Nationalism in Asia and Africa. New York: World Pub. Co., 1970. 1-52.

Lin, Yu-sheng (林艈生). The Crisis of Chinese Consciousness: Radical Antitraditionalism in the May Fourth Era. Madison: The University of Wisconsin Press, 1979.

Liu, Lydia (刘禾). Translingual Practice: Literature, National Culture, and Translated Modernity-China, $1900-1937$. Stanford: Stanford University Press, 1995

Lu，Xun (鲁迅). "狂人日记" ("A Madman's Diary") 1918. 新青年精选集 (1) (Selected Works of New Youth (1)). Beijing: zhongguo shudian, 2012. 365-72.

Lu, Xun (鲁迅). "A Madman's Diary." Trans. Gladys Yang. Silent China: Selected Writings of Lu Xun. Oxford: Oxford UP, 1973. 3-13.

Lu，Xun (鲁迅). "辩言" ("Preface"). 鲁迅大全集 (Collected Works of Lu Xun). Wuhan: Changjiang wenyi chubanshe， 2011. Vol. 11, 9-10.

Luo, Zhitian (罗志田). "近代中国民族主义的研究取向与反思" ("Reflections on the Research Orientations of Nationalism in Modern China"). 四川大学学报：哲学社会科学版 (Journal of Sichuan University) 1 (1998): 73-84.

Luo, Zhitian (罗志田). 潜流 : 民族主义与民国政治 (Nationalism and the Politics of Nationalist Party Government). Shanghai: Shanghai guji chubanshe, 2001.

Mao, Dun (茅盾). 我走过的路 (1) (The Road I Have Traveled). Beijing: renmin wenxue chubanshe, 1981.

Mao, Dun. "衣食住" ("Food, Clothing, and Shelter"). 茅盾译文全集 (Collected Translations of Dun Mao). Beijing: zhishi chanquan chubanshe, 2013. Vol. 10, 1-267.

O'Sullivan, Emer. Comparative Children's Literature. London: Routledge, 2005.

Plamenatz, John. "Two Types of Nationalism." International Relations in the Twentieth Century: A Reader. Ed. Marc Williams. Basingstoke: MacMillan, 1989. 44-56.

Qian, Liqun (钱理群). 周作人论 (On Zhou Zuoren). Shanghai: Shanghai People's P, 1991.

Qu, Qiubai (䨉秋白)， and Xun Lu (鲁迅). "关于翻译的通信" ("Correspondence on Translation"). 1931. 鲁迅全集 (Complete Works of Lu Xun. Vol. 4, 360-82.

Schwartz, Benjamin I. "Themes in Intellectual History: May Fourth and After." Ed. Merle Goldman and Leo Ou-Fan Lee. An Intellectual History of Modern China. Cambridge: Cambridge UP, 2002. 97-141.

Smith, Anthony D. "National Identity and the Idea of European Unity." International Affairs 68.1 (1992): $55-76$.

Tagore, Rabindranath. Stray Birds. New York: Macmillan, 1916.

Tagore, Rabindranath. The Crescent Moon. New York: Macmillan, 1913.

Tao, Dongfeng (陶东风). "现代中国的民族主义" ("Nationalism in Modern China"). 学术月刊 (Academic Monthly). Shanghai: Shanghaishi shehui kexuejie lianhehui, 6 (1995): 6-9.

Tolstoy, Leo. Anna Karenina. Trans. Constance Garnett. New York: Modern Library, 1950.

Verne, Jules G. Journey to the Center of the Earth. Trans. William Butcher. Oxford: Oxford UP, 1992.

Verne, Jules G. 地底旅行 (Journey to the Center of the Earth). Trans. Xun Lu (鲁迅). Wuhan: Changjiang wenyi chubanshe, 2011.

Wang, David Der-wei. Fin-de-Siècle Splendor: Repressed Modernities of Late Qing Fiction, 1849-1911. Stanford: Stanford UP, 1997.

Wu，Yu (吴虞). "吃人与礼教" ("People Eating and Feudal Ethics") 1919. 新青年精选集 (Selected Works of New Youth). Beijing: zhongguo shudian, 2012. Vol. 2, 291-94.

Zhang, Hao (张影). "重访五四：论五四思想的两歧性" ("Revisiting May Fourth: On the Dualism of May Fourth Thought"). 张浿自选集 (Hao Chang's Selected Essays). Shanghai: Shanghai jiaoyu chubanshe, 2002. $251-80$.

Zhang, Wei. What Is Enlightenment: Can China Answer Kant's Question? Albany: SU of New York P, 2010.

Zheng, Zhenduo (郑振铎). "花架之下" ("Underneath the Trellis"). 儿童文学 (Children's Literature). Shijiazhuang: Huashan wenyi chuban she, 1998. 198-205.

Zheng, Zhenduo (郑振铎). "两个生瘤的老人" ("Two Elders with Tumors"). 儿童文学 (Children's Literature). Shijiazhuang: Huashan wenyi chuban she, 1998. 183-85.

Zheng, Zhenduo (郑振铎). "儿童世界·第三卷的本志" ("Introduction to Children's World Vol. 3"). 儿童世界 (Children's World) 2.13 (1922): 46-47.

Zheng, Zhenduo (郑振铎). 儿童文学 (Children's Literature). Shijiazhuang: Huashan wenyi chuban she, 1998.

Zheng, Zhenduo (郑振铎). 外国文学文论 (Foreign Literature and Literary Theory). Shijiazhuang: Huashan wenyi chubanshe, 1998.

Zhou, Zuoren (周作人). "旧梦" ("Old Dreams"). 周作人先生文集：自己的园地 (Collected Works of Zhou Zuoren: A Garden of One's Own). Taibei: liren shuju, 1982. 151-54.

Zhou, Zuoren (周作人). "人的文学" ("A Humanist Literature"). 1918. 新青年精选集 (Selected Works of New Youth). Beijing: zhongguo shudian, 2012. Vol. 2, 152-57

Zhou, Zuoren (周作人). "随感录 二四)" ("Random Thoughts 24") 新青年 (New Youth) 5.3 (1918): 286-90.

Zhou, Zuoren (周作人). "侠女奴" ("Ali Baba and the Forty Thieves"). 周作人译文全集 (Collected Translations of Zhou Zuoren). Shanghai: Shanghai renmin chubanshe, 2012. Vol. 11, 3-27.

Zhou, Zuoren (周作人). "新文学的要求" ("Requirements for a New Literature") 1920. 艺术与生活 (Art and life). Hebei: Hebei Education P, 2002. 18-23. 
Author's profile: Chu Shen is working towards her Ph.D. in translation studies at Tsinghua University with a dissertation entitled Between Nationalism and Cosmopolitanism: Translation of Children's Literature in Early Twentieth-

Century China. Her interests in scholarship include the interplay between literary translation and intellectual history in modern China and the translation of modern Chinese literature including children's literature. Shen's publications include "The Literary Translator as Social Agent: Zhou Zuoren and the Literature for Children," neohelicon: acta comparationis litterarum unversarum (2014) and "Cosmopolitanism and the Translation of Children's Literature: Zheng Zhenduo as a Case Study," neohelicon: acta comparationis litterarum unversarum (2015). E-mail: <lisashentsinghua@gmail.com> 